\title{
Expression of TNF- $\alpha$ and IL-6 cytokines in the choroid and sclera of hypercholesterolemic rabbits
}

\author{
Expressão das citocinas TNF- $\alpha$ and IL-6 na coroide e esclera de coelhos hipercolesterolêmicos
}

Rogil José de Almeida Torres ${ }^{1}$, Andrea Luchinl², Lucas Younes Barberini ${ }^{1}$, Leonardo Precoma ${ }^{3}$, Caroline Luzia de Almeida Torres ${ }^{4}$, Robson Antonio de Almeida Torres ${ }^{4}$, Lucia de Noronha ${ }^{1}$, Bruna Olandoski Erbano ${ }^{5}$. Antonio Marcelo Barbante Casella ${ }^{6}$, Dalton Bertolim Precoma ${ }^{1}$

\begin{abstract}
Purpose: This study aimed to evaluate the expression of the inflammatory cytokines TNF- $\alpha$ and IL- 6 in the sclera and choroid of hypercholesterolemic rabbits. Method: Twenty-one New Zealand male albino rabbits were divided into two groups: NG and HG. The NG group was fed a standard rabbit diet and the HG group was fed a cholesterol-enriched diet (1\%). The serum total cholesterol, triglyceride, $\mathrm{HDL}$ cholesterol, and fasting blood glucose levels were determined at the beginning of the experiment and on the day of euthanasia. Euthanasia of animals in the NG and HG groups was performed at the end of the $4^{\text {th }}$ and $8^{\text {th }}$ week, respectively. The eyes were analyzed immunohistochemically using TNF- $\alpha$ and IL- 6 antibodies. Results: At the time of euthanasia, the HG group showed a significant increase in total cholesterol and triglyceride when compared with the NG group $(p<0.001)$. When compared with the NG group, there was a significant increase in the expression of TNF- $\alpha(p<0.001)$ and IL-6 $(p=0.002)$ in the choroid and sclera of animals in the HG group.
\end{abstract}

Conclusion: This study demonstrates that the hypercholesterolemic diet induces expression of TNF- $\alpha$ and IL- 6 in the choroid and sclera of rabbits.

Keywords: Cholesterol; Macrophages; Cytokines; Tumor necrosis factor; Interleukin-6; Choroid; Sclera; Macular degeneration

\section{RESUMO}

Objetivo: Avaliar a expressão das citocinas inflamatórias TNF- $\alpha$ e IL-6 na esclera e coroide de coelhos hipercolesterolêmicos.

Método: Coelhos New Zealand foram organizados em dois grupos: GN recebeu ração padrão para coelhos; GH recebeu dieta rica em colesterol a 1\%. Foi realizada a dosagem sérica de colesterol total, triglicerídeos, HDL colesterol, glicemia de jejum no início do experimento e no momento da eutanásia. Ao final da 4 a semana para o GN e 8 semana para o GH foi realizada a eutanásia dos animais. Os olhos foram submetidos à análise imuno-histoquímica com os anticorpos TNF- $\alpha$ e IL-6.

Resultados: $O$ GH manifestou significativo aumento do colesterol total e triglicerídeos em relação ao GN $(p<0,001)$. Houve significativo aumento da expressão da TNF- $\alpha$ $(p<0,001)$ e da IL-6 $(p=0,002)$ na coroide e esclera dos animais do GHem relação ao GN. Conclusão: Esteestudo demonstra que a dieta hipercolesterolêmica induz ao aumento da expressão das citocinas TNF- $\alpha$ e IL-6 na coroide e esclera de coelhos.

Descritores: Colesterol; Macrófagos; Citocinas; Fator de necrose tumoral; Interleucina-6; Coroide; Esclera; Degeneração macular

\section{INTRODUCTION}

The inflammation, as an inducer of diseases, is no longer exclusively associated with autoimmune and infectious diseases. Convincing experimental evidence and many histopathological findings support the current view of inflammation as a critical regulator in Age-Related Macular Degeneration (AMD) ${ }^{(1,2)}$. Macrophages, retinal pigment epithelial (RPE) cells, and endothelial cells (EC) play an important role in the pathogenesis of ocular inflammation and the consequent formation of subretinal neovascular membrane (CNV). These cells secrete various inflammatory, growth, and angiogenic factors as well as pro-inflammatory cytokines, which contribute to the development of wet $\mathrm{AMD}^{(3-5)}$. The role of growth factors, such as vascular endothelial growth factor (VEGF), on the formation of CNV has been identified. However, the influence and the mechanism of action of the inflammatory cytokines on the development of exudative AMD are poorly understood. It has been reported that signaling events initiated by cytokines trigger the inflammatory reaction and contribute to the development of $\mathrm{CNV}^{(6)}$.

The tumor necrosis factor alpha (TNF- $\alpha$ ) is a low-molecular weight protein, primarily produced by activated macrophages. TNF- $\alpha$ promotes VEGF signaling by promoting its production ${ }^{(7)}$ and by modulating the expression of its receptors ${ }^{(8)}$. It has been reported that TNF- $\alpha$ regulates cell survival and cell death through Tnfrsf1 $a$ and Tnfrsf1 $b$ receptor. Activation of Tnfrsfla receptors induces inflammation, inhibits endothelial cell migration and apoptosis ${ }^{(9)}$, which may inhibit CNV. The Tnfrsf $1 \mathrm{~b}$ receptors regulate lymphocyte proliferation ${ }^{(10)}$ and promote endothelial cell activation, migration, and survival|(11). It has been reported that Tnfrsf1b promotes $C N V^{(12)}$. Studies have demonstrated that therapeutic targeting of TNF-a may provide benefits from CNV ${ }^{(12-15)}$. TNF- $\alpha$ stimulates the production of Interleukin 6 (IL-6) $)^{(16)}$, a multifunctional cytokine that acts on a number of tissues and cell types ${ }^{(17)}$. IL-6 is an important mediator of the inflammatory and immune respon$\operatorname{ses}^{(18)}$, and regulates VEGF expression ${ }^{(19)}$.
Funding: No specific financial support was available for this study.

Disclosure of potential conflicts of interest: None of the authors have any potential conflicts of interest to disclose.

Corresponding author: Rogil Jose de Almeida Torres. Rua Emiliano Perneta, 390 - Conj. 1.407 Curitiba (PR) - 80420-080 - Brazil - E-mail: rjat@terra.com.br

Project Number 240/080. CEUA - Pontifícia Universidade Católica do Paraná.

CEUA Authorization Registration: 678- $2^{\text {nd }}$ version.

Authorization Date: 08/24/2012. 
These cytokines play direct and/or indirect roles in the development of AMD. However, few reliable experimental models exist that simulate the development of macular degenerative diseases.

The objective of this study was to evaluate the expression of the inflammatory cytokines TNF- $\alpha$ and IL- 6 in the choroid and sclera of hypercholesterolemic rabbits.

\section{METHODS}

The protocol for this study was approved by the Animal Experimentation Ethics Committee of the Pontifícia Universidade Católica do Paraná (PUC-PR) and complies with the guidelines established by the Declaration of Helsinki and the Association for Research in Vision and Ophthalmology (ARVO).

\section{EXPERIMENT ENVIRONMENT}

The procedures described in this study were performed at the Surgical Technique Laboratory at PUC-PR and at the Study Center of the Angelina Caron Hospital (HAC). The animals were housed in the bioterium (macro environment) under 12h:12h light-dark cycles with air changes and between 19 and $23^{\circ} \mathrm{C}$ room temperature. Animals were fed water ad libitum and were allowed free access to species standard diet Nuvital ${ }^{\circledast}$ (Nuvital, Colombo, Brazil).

\section{Animals AND EXPERIMENTAL METHOdS}

Twenty-one New Zealand male albino rabbits (Oryctolaguscunicullus) of an average age of 110 days and an average weight of $2.770 \mathrm{~g}$ were selected from the Central Bioterium of the Pontifícia Universidade Católica do Paraná. The animals were divided into 2 groups: group 1, the normal diet group (NG) with 8 rabbits, and group 2, the hypercholesterolemic group $(\mathrm{HG})$ with 13 rabbits. The NG was fed the rabbit standard diet from Nuvita ${ }^{\circledR}$ Lab (Nuvital, Colombo, Brazil) and was euthanized after 4 weeks. The HG group was fed with the standard rabbit diet from Nuvital${ }^{\circledR}$ Lab (Nuvital, Colombo, Brazil), supplemented with 1\% cholesterol. The daily amount of diet per animal was $600 \mathrm{~g}$. The animals in the HG group were euthanized at the end of the eighth week.

Each rabbit underwent measurements of serum total cholesterol, triglycerides, HDL cholesterol, and fasting glucose at the start of the experiment and at the time of euthanasia. Animals were euthanized by intravenous administration of $5 \mathrm{~mL}$ pentobarbital. The eyes were removed and immediately placed in 4\% paraformaldehyde (Merck, Darmstadt, Germany) in 0.1 M phosphate buffer ( $\mathrm{pH} 7.4)$ for $4 \mathrm{~h}$ for immunohistochemical analyses.

\section{TISSUE PREPARATION AND IMMUNOHISTOCHEMICAL ANALYSIS}

After fixation, the samples were evaluated under a microscope. A coronal section at the level of the optic nerve was performed and the ocular globe was divided into two equal halves. The lower half was stored for future studies. The upper half underwent dehydration, diaphanization, and was embedded in paraffin using a Leica ${ }^{\oplus}$ TP 1020 Automatic Tissue Processor (Leica, Wetzlar, Germany). A Leica ${ }^{\circledR}$ EG1 160 paraffin embedding device was used for paraffin embedding. A Leica ${ }^{\oplus}$ RM2145 Microtome was used to prepare 5-micron-thick sections for histology. The sections were placed on glass slides smeared with albumin, stained with hematoxylin-eosin, and mounted on 24x900-mm coverslips using the Entellan Mounting Media (Merck, Darmstadt, Germany).

The sections were deparaffinized, rehydrated, and the endogenous peroxidases were blocked. The sections were then washed with deionized water and incubated in a moist chamber at $95^{\circ} \mathrm{C}$ for 20 min for antigen retrieval. Following this, the endogenous peroxidases were blocked again. The slices were stained with rabbit primary monoclonal antibody against TNF- $\alpha$ (Imuny Biotechnology, Campinas, Brazil) at a dilution of 1:200 and with rabbit primary monoclonal antibody against IL-6 (Imuny Biotechnology, Campinas, Brazil) at a dilution of 1:50. The slices were incubated with a secondary antibody, Envision ${ }^{\circledast}$ System labeled polymer-HRP anti-mouse (DakoCytomation, Carpinteria, CA, USA), at room temperature for $30 \mathrm{~min}$. The sections were incubated for 3 to 5 min with freshly prepared DAB substrate (DakoCytomation, Carpinteria, CA, USA). The slides were then counterstained with Mayer hematoxylin and mounted.

Positive and negative controls were used in all evaluations, and the slides were initially analyzed by a masked observer. Positive and negative staining detected for TNF- $\alpha$ and IL- 6 were recorded. The immunopositive areas showed a brownish color and were studied using color morphometry. For this purpose, images of 3 consecutive fields close to the optic nerve head were captured with the help of a Bx50 Olympus microscope fitted with a 40x objective and equipped with a Sony Model DXC-107A camera. The program Image Pro Plus was used to select and color the immunopositive areas and measure the immunoreactive areas. The data obtained were compiled in a Microsoft Excel spreadsheet (Redmond, WA) for statistical analysis. The sum total of all immunopositive areas in each of the 3 fields studied represented the variable immunoreactive area.

\section{Statistical analysis}

The t-test was used for the comparison of quantitative variables between the groups. The Mann-Whitney nonparametric test was also used when appropriate. The normality was evaluated with the Shapiro-Wilk test. $p<0.05$ indicated statistical significance. Statistica v. 8.0 was used for data processing.

\section{RESULTS}

\section{Comparison of variables between NG and HG groups: FASTING GLUCOSE, TOTAL CHOLESTEROL, HDL, AND TRIGLYCERIDES}

The total cholesterol, triglycerides, HDL cholesterol, and the fasting glucose in the NG group at the time of euthanasia were similar to those at the start of the experiment. However, in the HG group, the total cholesterol at the time of euthanasia was significantly higher than that of at the start of the experiment. At the start of the experiment, the mean of the total cholesterol in both the groups was approximately $41.3 \mathrm{mg} / \mathrm{dL}$. However, by the end of the experiment, the total serum cholesterol in the $\mathrm{HG}$ group had increased by $2146.8 \mathrm{mg} / \mathrm{dL}(\mathrm{p}<0.001)$. HG group also showed significant variation in serum triglyceride levels. At the start of the experiment, the serum triglyceride concentration was approximately $46.5 \mathrm{mg} / \mathrm{dL}$ in both the groups, whereas at the time of euthanasia, the serum triglyceride concentration was $168.5 \mathrm{mg} / \mathrm{dL}(\mathrm{p}=0.001)$ in $\mathrm{HG}$ group. Fasting glucose and HDL cholesterol levels did not vary significantly in NG or HG group during the experiment.

\section{Comparison of TNF- $\alpha$ IMmUNOREActivities OF the NG AND HG GROUPS}

The animals in the HG group showed a significant increase in TNF- $\alpha$ expression in the sclera and choroid when compared to the animals in the NG group $(p<0.001)$ (Table 1). This was characterized by the predominance of a brownish hue of these structures (Figure 1B). The sclera and the choroid in the NG group showed a bluish color and a thinner structure compared with the HG group, revealing low immunoreactivity of these structures in NG group to the TNF- $\alpha$ antibody (Figure 1A).

\section{Comparison OF IL-6 IMMUNOREActivities OF THE NG AND HG GROUP}

Compared with the NG group, the sclera and choroid of the $\mathrm{HG}$ group showed a significant increase in IL-6 expression $(p=0.002)$ (Table 2), characterized by the predominance of the brownish hue of these structures (Figure 2B). The sclera and choroid of the animals 
in the NG group showed a thinner structure and a predominant bluish color than those of the animals in the HG group, revealing low immunoreactivity of these structures in NG group to IL-6 antibody (Figure 2A).

\section{DISCUSSION}

Angiogenesis, the formation of new blood vessels from pre-existing endothelium, is an important event during vascular development, wound healing, and organ regeneration. Angiogenesis and neovascularization during tumor growth, diabetic retinopathy, rheumatoid arthritis, and AMD produce detrimental effects $(20,21)$.
The critical role of VEGF in angiogenesis is well documented. However, it has been demonstrated that inflammatory reaction, characterized by the presence of macrophages and inflammatory cytokines, also induces the anomalous formation of blood vessels ${ }^{(22)}$. That inflammation mediates neovascularization in AMD is supported by studies that suggested depletion of macrophages can reduce the laser-induced CNV ${ }^{(23)}$.

In the present study, rabbits were fed with cholesterol enriched diet to evaluate the expression of the TNF- $\alpha$ and IL- 6 in the choroidscleral complex. It has been reported that cholesterol-enriched diet induces hypoxia of the retinal tissue ${ }^{(24)}$, increase in the macrophage concentration in the choroid and sclera ${ }^{(24-25)}$, as well as increase in

Table 1. Total area of the choroidscleral complex immunoreactive to TNF-a

\begin{tabular}{lcccccccc}
\hline Variable & Group & N & Mean & Median & Min & Max & $\begin{array}{c}\text { Standard } \\
\text { deviation }\end{array}$ & p*value $^{*}$ \\
\hline Immunoreactive area & HG & 13 & 60317.2 & 51130.9 & 24613.5 & 105314.6 & 28857.7 & \\
& NG & 8 & 7134.2 & 6686.2 & 1635.9 & 22214.6 & 6626.0 & $<0.001$ \\
\hline
\end{tabular}

* $=$ Student's t-test for independente samples, $\mathrm{p}<0.05$.

$\mathrm{NG}=$ normal diet group; $\mathrm{HG}=$ cholesterol-enriched diet group.

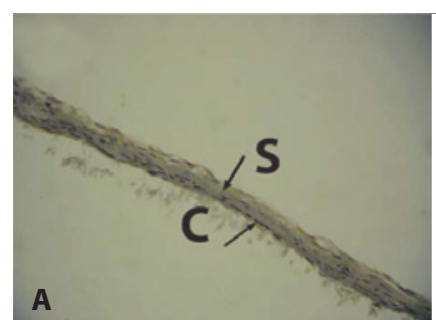

$\mathrm{C}=$ choroid; $\mathrm{S}=$ sclera; magnification $=400 \mathrm{x}$.

Figure 1. Immunoreactivity of choroid and sclera to TNF-a antibody. A) Choroid-scleral complex of normal diet group. Predominance of the bluish hue indicates low immunoreactivity to TNF- $\alpha$ antibody. Thin choroid and sclera. B) Choroid-sclera complex of hypercholesterolemic group. Predominance of a brownish hue indicates high immunoreactivity to TNF- $\alpha$ antibody. Thick choroid and sclera. reactivity to TNF- $\alpha$ antibody. Thick choroid and sclera.

Table 2. Total área of the choroidscleral complex immunoreactive to IL-6

\begin{tabular}{lcccccccc}
\hline \multirow{2}{*}{ Variable } & Group & N & Mean & Median & Min & Max & $\begin{array}{c}\text { Standard } \\
\text { deviation }\end{array}$ & p* value \\
\hline Immunoreactive area & HG & 13 & 5301.0 & 5138.0 & 1963.0 & 9551.0 & 2590.0 & \\
& NG & 8 & 2427.0 & 2427.0 & 987.0 & 3968.0 & 893.0 & 0.002 \\
\hline
\end{tabular}

* $=$ Student's t-test for independente samples, $\mathrm{p}<0.05$.

$\mathrm{NG}=$ normal diet group; $\mathrm{HG}=$ cholesterol-enriched diet group
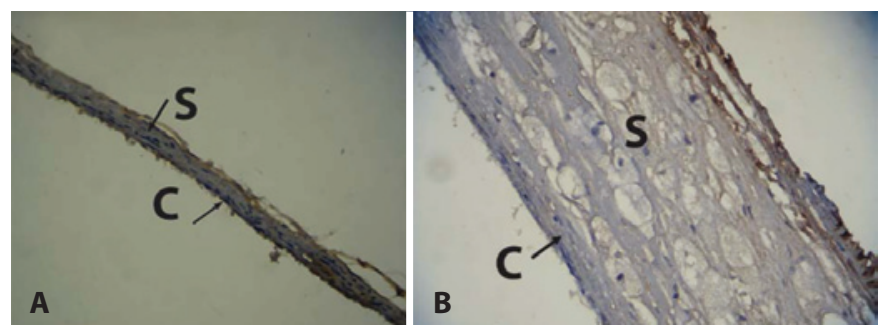

$\mathrm{C}=$ choroid $\mathrm{S}=$ sclera; magnification $=400 \mathrm{x}$.

Figure 2. Immunoreactivity of choroid and sclera to IL-6 antibody. A) Choroid and sclera of normal diet group. Predominance of the bluish hue indicates low immunoreactivity to IL- 6 antibody. Thin choroid and sclera. B) Choroid and sclera of hypercholesterolemic group. Predominance of a brownish hue indicates high immunoreactivity to IL-6 antibody. Thick choroid and sclera. 
VEGF expression in these structures ${ }^{(25)}$. Therefore, the significant increase in the TNF- $\alpha$ expression observed in the choroid and sclera of the animals in the HG group was likely due to hypoxia, as well as an increase in the macrophage concentration ${ }^{(26)}$. TNF- $\alpha$ is a multifunctional cytokine. TNF- $\alpha$ receptors are expressed in the retina, including the Muller and the RPE cells, as well as in the choroid ${ }^{(6,13-14)}$ The TNF- $\alpha$ secreted by macrophages ${ }^{(22)}$, observed in a large numbers in this experimental model (24-26), triggers the production of VEGF through Tnfrsf1b receptor by the RPE cells ${ }^{(6)}$. TNF- $\alpha$ also stimulates monocyte adhesion and upregulates the granulocyte-macrophage colony-stimulating factor ${ }^{(27)}$. Additionally, TNF induces EC migration and tube formation in the absence of proangiogenic factors, suggesting that TNF can directly activate signaling pathways for epithelial cell migration ${ }^{(27)}$, thereby contributing directly to CNV formation. Indeed, TNF has been considered a therapeutic target in exudative AMD. Although the inhibition of TNF- $\alpha$ leads to the reduction in CNV size and leakage in experimental models ${ }^{(13)}$, clinical research studies have shown inconsistent results ${ }^{(16,28)}$

It has also been demonstrated that TNF- $\alpha$ stimulates the production of IL-6 ${ }^{(16)}$, an important marker of inflammation. RPE and inflammatory cells produce IL-6 in response to stimulation ${ }^{(5,16,29)}$. In the present study, a significant increase in the IL-6 expression was observed in the choroid and sclera of the rabbits in the HG group. Besides TNF- $\alpha^{(16)}$, the macrophages and the hypoxia may have contributed to the increased IL-6 expression ${ }^{(19,24)}$. It has been demonstrated that the induction of IL- 6 by hypoxia may induce VEGF expression, leading to angiogenesis. Therefore, IL- 6 is regarded as indirect angiogenic factor ${ }^{(19)}$. Further, it has been shown that the inhibition of the IL-6 expression by the pharmacologic blockade of its receptors or by the genetic ablation of this cytokine suppresses laser-induced CNV ${ }^{(29)}$. The IL-6 receptor neutralization led to significant inhibition of the in vivo and in vitro expression of monocyte chemotactic protein, intercellular adhesion molecule-1, and vascular endothelial growth factor, and reduced macrophage infiltration into $\mathrm{CNV}^{(29)}$. Consistent with these reports, a population study concluded that IL-6 represents a risk factor for CNV due to high levels in the plasma of AMD patients ${ }^{(30)}$. These findings suggest the possibility of using IL- 6 receptor blockade as a therapeutic strategy to suppress CNV associated with age-related macular degeneration.

We used rabbits for this research. The advantages of using rabbits over other animals include increased availability, low costs (when compared with transgenic mice lacking receptors for $L D L$ cholesterol or apolipoprotein E), and a better genetic characterization ${ }^{(31)}$. Additionally, the hypercholesterolemic diet rapidly induces endothelial dysfunction and a response similar to atherogenesis, making it a good model for cardiovascular diseases ${ }^{(32)}$. Further, the normal serum cholesterol levels in rabbits range from 25 to $60 \mathrm{mg} \%$, whereas in humans this variation is between 100 and $200 \mathrm{mg} \%$. Therefore, the metabolic system of rabbits may readily be overloaded with a simple daily hypercholesterolemic diet, making the experiments more feasible and reproducible ${ }^{(32)}$. Indeed, the total serum cholesterol level in HG group increased from $41.3 \mathrm{mg} / \mathrm{dL}$ at the start of the experiment to approximately $2146.8 \mathrm{mg} / \mathrm{dL}$ at the time of euthanasia.

Several studies have been performed on rabbits to demonstrate that a cholesterol-enriched diet causes abnormalities in their sclera, choroid, and retina. This include the administration of $0.5 \%$ cholesterol-enriched diet for at least six months ${ }^{(33,34)}$. In this study, the administered dosage of cholesterol was higher than that used in other studies ( $1 \%$ cholesterol), which enabled the authors to obtain immunohistochemical alterations of the choroid-sclera complex during a period of eight weeks. This demonstrated that alterations in the ocular walls as well as the arteries ${ }^{(32)}$ could be brought about in a shorter period, thus offering opportunities for more experiments and reducing the costs. The NG group underwent euthanasia after 4 weeks. This short period has been proven to be sufficient to demonstrate that the serum total cholesterol, triglycerides, HDL cholesterol, and fasting glucose level remained stable and did not interfere with the immunohistochemical analysis of the choroid and sclera. The decision to euthanize rabbits of the NG group after 4 weeks was made based on the results of earlier studies ${ }^{(24,35)}$.

We have demonstrated that cholesterol-enriched diet induces an increase in macrophage concentration in the choroid-sclera complex, causing thickness of these structures ${ }^{(24,25,35)}$. The diet also induced hypoxia of the retinal tissue, leading to neuronal damage ${ }^{(35)}$. Therefore, the hypercholesterolemic model used in the present study incorporates the increased macrophage concentration and hypoxia, the two conditions that induce TNF- $\alpha$ and IL-6 expression ${ }^{(19,22,24)}$.

\section{CONCLUSION}

In this study, we used immunohistochemistry to analyze the expression of TNF- $\alpha$ and IL-6 in the sclera and choroid of hypercholesterolemic rabbits. Although Western blotting is a more sensitive method for the detection of these factors, it requires the use of fresh or frozen tissue. Since the ocular globes were fixed in paraformaldehyde and embedded in paraffin, we were unable to use the Western blotting technique.

Due to their role in mediating the intraocular inflammatory reaction, VEGF-like functions, and their hypoxia-induced expression, TNF- $\alpha$ and IL-6 have been considered as therapeutic targets in AMD. Our experimental model may help understand the development of AMD.

\section{ACKNOWLEGMENTS}

We thank Dr. Márcia Olandoski for assisting with the statistical analysis of data.

\section{REFERENCES}

1. Anderson DH, Mullins RF, Hageman GS, Johnson LV. A role for local inflammation in the formation of drusen in the aging eye. Am J Ophthalmol. 2002;134(3):411-31.

2. Penfold PL, Madigan MC, Gillies MC, Provis JM. Immunological and aetiological aspects of macular degeneration. Prog Retin Eye Res. 2001;20(3):385-414.

3. Grossniklaus HE, Ling JX, Wallace TM, Dithmar S, Lawson DH, Cohen C, et al. Macrophage and retinal pigment epithelium expression of angiogenic cytokines in choroidal neovascularization. Mol Vis. 2002;8:119-26.

4. Tsutsumi C, Sonoda KH, Egashira K, Qiao H, Hisatomi T, Nakao S, et al. The critical role of ocular-infiltration macrophages in the development of choroidal neovascularization. J Leukoc Biol. 2003;74(1):25-32.

5. Planck SR, Dang TT, Graves D, Tara D, Ansel JC, Rosenbaum JT. Retinal pigment epithelial cells secrete interleukin-6 in response to Interleukin-1. Invest Ophthalmol Vis Sci. 1992;33(1):78-82.

6. Oh H, Takagi H, Takagi C, Suzuma K, Otani A, Ishida K, et al. The potential angiogenic role of macrophages in the formation of choroidal neovascular membranes. Invest Ophthalmol Vis Sci.1999:40(9):1891-8.

7. Ryuto M, Ono M, Izumi H, Yoshida S, Weich HA, Kohno K, et al. Induction of vascular endothelial growth factor by tumor necrosis factor alpha in human glioma cells. Possible roles of SP-1. J Biol Chem. 1996;271(1):28220-8.

8. Patterson C, Perrella MA, Endege WO, Yoshizumi M, Lee ME, Haber E. Downregulation of vascular endothelial growth factor receptors by tumor necrosis factor-alpha in cultured human vascular endothelial cells. J Clin Invest. 1996;98(2):490-6.

9. Hsu H, Shu HB, Pan MG, Goeddel DV.TRADD-TRAF2 and TRADD-FADD interactions define two distinct TNF receptor 1 signal transduction pathways. Cell. 1996;84(2):299-308.

10. Wallach D, Arumugam TU, Boldin MP, Cantarella G, Ganesh KA, Goltsev Y, et al. How are the regulators regulated? The search for mechanisms that impose specificity on induction of cell death and NF-kB activation by members of the TNF/NGF receptor family. Arthritis Res. 2002;4 Suppl 3:S189-96.

11. Pan S, An P, Zhang R, He X, Yin G, Min W. Etk/Bmx as a tumor necrosis factor receptor type 2-specific kinase: role in endothelial cell migration and angiogenesis. Moll Cell Biol. 2002;22(21):7512-23.

12. Semkova I, Muether PS, Kuebbeler M, Meyer KL, Kociok N, Joussen AM. Recruitment of blood-derived inflammatory cells mediated via tumor necrosis factor- receptor $1 \mathrm{~b}$ exacerbates choroidal neovascularization. Invest Ophthalmol Vis Sci. 2011:52(11):6101-8.

13. Shi X, Semkova I, Müther PS, Dell S; Kociok N, Joussen AM. Inhibition of TNF-alpha reduces laser-induced choroidal neovascularization. Exp Eye Res. 2006;83(6):1325-34.

14. Majka S, McGuire PG, Das A. Regulation of matrix metalloproteinase expression by tumor necrosis factor in a murine model of retinal neovascularization. Invest Ophthalmol Vis Sci. 2002;43(1):260-6 
15. Theodossiadis PG, Liarakos VS, Sfikakis PP, Vergados IA, Theodossiadis GP. Intravitreal administration of the anti-tumor necrosis factor agent infliximab for neovascular age-related macular degeneration. Am J Ophthalmol. 2009;14(5)7:825-30. Comment in: Am J Ophthalmol. 2009;147(5):761-3.

16. Elner VM, Scales W, Elner SG, Danforth J, Kunkel SL, Strieter RM. Interleukin-6 (IL-6) gene expression and secretion by cytokine-stimulated human retinal pigment epithelial cells. Exp Eye Res. 1992:54(3):361-8.

17. Van Snick J. Interleukin-6: an overview. Annu Rev Immunol.1990;8:253-78.

18. Kopf M, Baumann H, Freer G, Freudenberg M, Lamers M, Kishimoto T, et al. Impaired immune and acute-phase responses in interleukin-6-defiecient mice. Nature. 1994; 368(6469):339-42.

19. Cohen T, Nahari D, Cerem LW, Gera N, Levi B. Interleukin-6 induces the expression of vascular endothelial growth factor. J Biol Chem.1996;271(2):736-41.

20. Risau W. Mechanisms of angiogenesis. Nature.1997;386:671-4.

21. Ambati J, Ambati BK, Yoo SH, lanchulev S, Adamis AP. Age-related macular degeneration: etiology, pathogenesis, and therapeutic strategies. Surv Ophthalmol. 2003;48(3): 257-93.

22. Leibovich SJ, Polverini PJ, Shepard HM, Wiseman DM, Shively V, Nuseir N. Macrophage-induced angiogenesis is mediated by tumor necrosis factor-alpha. Nature. 1987; 329(6140):630-2.

23. Espinosa-Heidmann DG, Suner IJ, Hernandez EP, Monroy D, Csaky KG, Cousins SW. Macrophage depletion diminishes lesion size and severity in experimental choroidal neovascularization. Invest Ophthalmol Vis Sci. 2003:44(8):3586-92.

24. Torres RJ, Muccioli C, Maia M, Noronha L, Luchini A, Alessi A, et al. Sclerochorioretinal abnormalities in hypercholesterolemic rabbits treated with rosiglitazone. Ophthalmic Surg Lasers Imaging. 2010:41(5):562-71.

25. Torres RJ, de Noronha L, Casella AM, Torres R do R, Martins Ide C, Zotz R, et al. Increased VEGFR-1 immunoreactivity in the choroid-scleral complex in hypercholesterolemia experimental model. Arq Bras Oftalmol. 2013;76(1):1-5.
26. Naldini A, Carraro F, Silvestri S, Bocci V. Hypoxia affects cytokine production and proliferative responses by human peripheral mononuclear cells.J Cell Physiol.1997:173(3): 335-42.

27. Frater-Schroder M, Risau W, Hallmann R, Gautschi P, Bohlen P. Tumor necrosis factor type alpha, a potent inhibitor of endothelial cell growth in vitro, is angiogenic in vivo. Proc Natl Acad Sci USA. 1987:84(15):5277-81

28. Wu L, Arevalo JF, Hernandez-Bogantes E, Regatieri CV, Roca JÁ, Farah ME. Intravitreal tumor necrosis factor-alpha inhibitors for neovascular age-related macular degeneration suboptimally responsive to antivascular endothelial growth factor agents: a pilot study from the Pan American Collaborative Retina Study Group. J Ocul Pharmacol Ther. 2013;29(3):366-71.

29. Izumi-Nagai K, Nagai N, Ozawa Y, Mihara M, Ohsugi Y, Kurihara T, et al. Interleukin-6 re ceptor-mediated activation of signal transducer and activator of transcription-3 (STAT3) promotes choroidal neovascularization. Am J Pathol. 2007;170(6):2149-58.

30. Seddon JM, George S, Rosner B, Rifai N. Progression of age-related macular degeneration: prospective assessment of C-reactive protein, interleukin 6, and other cardiovascular biomarkers. Arch Ophthalmol. 2005;123(6):774-82

31. Kantor B, Ashai K, Holmes DR, Schwartz RS. The experimental animal models for asses sing treatment of restenosis. Cardiovasc Radiation Med. 1999;1(1):48-54.

32. Sun YP, Lu NC, Parmley YWW, Hollenbeck CB. Effects of cholesterol diets on vascular function and atherogenesis in rabbits. Proc Soc Exp Biol Med. 2000;224(3):166-71.

33. Salazar JJ, Ramírez Al, de Hoz R, Rojas B, Ruiz E, Tejerina T, et al. Alterations in the choroid in hypercholesterolemic rabbits: reversibility after normalization of cholestero levels. Exp Eye Res. 2007:84(3):412-22.

34. Triviño A, Ramírez Al, Salazar JJ, de Hoz R, Rojas B, Padilla E, et al. A cholesterol-enriched diet induces ultrastructural changes in retinal and macroglial rabbit cells. Exp Eye Res. 2006:83(2):357-66.

35. Torres RJ, de Noronha L, Casella AM, Grobe SF, Martins Ide C, Torres Rdo R, et al. Effect of olmesartan on leukocyte recruitment in choroid-sclera complex in hypercholesterolemia model. J Ocul Pharmacol Ther. 2013:29(8):709-14.

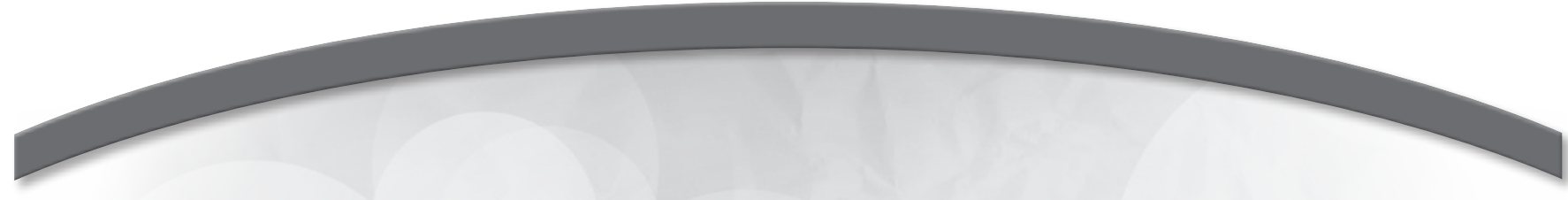

\title{
VII Congresso Baiano de Oftalmologia
}

\author{
10 e 11 de outubro de 2014 \\ Hotel Sheraton \\ Salvador - BA
}

\section{Informações:}

Site: www.sofba.com..br 